\title{
PENGARUH REBUSAN LIDAH BUAYA (Aloe Vera L) TERHADAP KADAR GULA DARAH PADA PASIEN DIABETES MELITUS TIPE 2
}

\author{
Novita Aryani ${ }^{1}$, Rinco Siregar ${ }^{2}$, Bika Utami ${ }^{3}$ \\ 1,2,3 Program Studi Ners, Universitas Sari Mutiara Indonesia \\ Email: ${ }^{1}$ novitaaryaniusm@gmail.com, ${ }^{2}$ rincosiregar@gmail.com, ${ }^{3}$ bikautami23@gmail.com
}

\begin{abstract}
ABSTRAK
Pentingnya pengendalian kadar gula darah pasien diabetes melitus tipe 2 secara nonfarmakologis berguna untuk mengurangi resiko bagi kesehatan tubuh. Lidah buaya (aloe vera, l) mengandung banyak unsur mineral dan antioksidan alami yang dapat meningkatkan kondisi kesehatan tubuh termasuk organ pankreas pasien diabetes melituss tipe 2. Tujuan penelitian ini untuk mengetahui pengaruh rebusan lidah buaya (aloe vera l) terhadap kadar gula darah penderita diabetes melitus tipe 2. Jenis penelitian iniadalah pre eksperimen analitik komparatif dengan rancangan penelitian desain Pre \& Post Test Without Control. Populasi dalam penelitian adalah seluruh pasien diabetes melitus tipe 2 yang berobat rawat jalan di Puskesmas Kelurahan Kebun Lada Kecamatan Binjai Utara tahun 2020. Pengambilan sampel dilakukan dengan teknik purposive sampling dan untuk menentukan jumlah sampel pada populasi penelitian ini yang tidak diketahui jumlahnya maka besarnya sampel dihitung dengan menggunakan tabel Cohen dengan Power 90 serta effect size 1.20 sehingga diperoleh 13 orang responden. Perlakuan pemberian rebusan lidah buaya dilakukan selama 7 hari setelah makan malam. Pengukuran kadar gula darah dilakukan sebanyak dua kali yaitu sebelum dan setelah dilakukan intervensi. Rebusan lidah buaya terbuat dari lidah buaya seberat $75 \mathrm{mg}$ yang direbus dengan $300 \mathrm{ml}$ air sampai mendidih. Tehnik analisa data menggunakan uji statistik Wilcoxon Macthed Paired Sign Rank Test. Hasil pengukuran pre dan post perlakuan didapati rata-rata sebesar 319,85 mg/dl dan 299,62 $\mathrm{mg} / \mathrm{dl}$. Terjadi penurunan sebesar 20.23 $m g / d l$ dengan nilai $Z=-3,183$ dan dengan nilai $p$ value $=0,001(p<0,05)$. Ini berarti pemberian rebusan lidah buaya berpengaruh secara signifikan pada penurunan kadar gula darah pasien diabetes melitus tipe 2 di Puskesmas Kelurahan Kebun Lada Kecamatan Binjai Utara. Diharapkan kepada pasien diabetes melitus tipe 2 agar terus mengkonsumsi rebusan lidah buaya dan jangan lupa untuk selalu melakukan pemeriksaan rutin kadar gula darah di pelayanan kesehatan terdekat.
\end{abstract}

Kata Kunci: Rebusan Lidah Buaya, Diabetes Melitus Type 2, Kadar Gula Darah.

\section{ABSTRACT}

The importance of controlling blood sugar levels in patients with type 2 diabetes mellitus nonpharmacologically is useful for reducing risks to body health. Aloe vera (aloe vera, l) contains many mineral elements and natural antioxidants that can improve the health condition of the body including the pancreas of patients with diabetes mellitus type 2. This type of research is a comparative analytic preexperiment with Pre \& Post Test without Control research design. The population in the study were all patients with type 2 diabetes mellitus who received outpatient treatment at the Puskesmas Kelurahan Kebun Lada, North Binjai District in 2020. Sampling was carried out by purposive sampling technique and to determine the number of samples in this study population whose number was unknown, the sample size was calculated by using Cohen's table with a power of 90 and an effect size of 1.20 so that 13 respondents were obtained. The treatment of giving aloe vera decoction was carried out for 7 days after dinner. Measurement of blood sugar levels was carried out twice, namely before and after the intervention. Aloe vera decoction is made from aloe vera weighing $75 \mathrm{mg}$ which is boiled with $300 \mathrm{ml}$ of water until it boils. The data analysis technique used the Wilcoxon Matched Paired Sign Rank Test statistical test. The results of the pre and post treatment measurements were found to be on average $319.85 \mathrm{mg} / \mathrm{dl}$ and $299.62 \mathrm{mg} / \mathrm{dl}$. There was a decrease of $20.23 \mathrm{mg} / \mathrm{dl}$ with a value of $Z=-3.183$ and with a value of $p$ value $=0.001(p<0.05)$. This means that giving aloe vera decoction has a significant effect on reducing blood sugar levels in type 2 diabetes mellitus patients at the Puskesmas Kebun Lada, North Binjai District. It is hoped that patients with type 2 diabetes mellitus will continue to consume aloe veradecoction and do not forget to always carry out regular checks of blood sugar levels at the nearest health service. 


\section{PENDAHULUAN}

Diabetes melitus (DM) merupakan masalah kesehatan masyarakat dunia dan menjadi prioritas yang penting serta termasuk empat penyakit tidak menular yang menjadi target tindak lanjut oleh para pemimpin dunia. Menurut data dari International Diabetes Federation (IDF) tahun 2019 sedikitnya sekitar 436 juta orang pada usia 20-70 tahun di dunia menderita diabetes atau setara dengan angka prevalensi sebesar 9,3\% dari total penduduk pada usia yang sama dan Indonesia berada di peringkat ketujuh diantara 10 negara dengan jumlah penderita terbanyak, yaitu sebesar 10,7 juta orang. Indonesia merupakan satu-satunya negara di Asia Tenggara yang ada pada daftar 10 negara dengan jumlah penderita diabetes tertinggi di dunia (Kementrian Kesehatan Republik Indonesia, 2020).

DM adalah penyakit kronis serius yang terjadi karena adanya kekurangan insulin secara relatif maupun absolut. Defisiensi insulin pada pasien DM terjadi melalui 3 jalur, yaitu: a. rusaknya sel-sel B pankreas karena pengaruh dari luar (virus, zat kimia, dll) b. desensitasi atau penurunan reseptor glukosa pada kelenjar pankreas, c. desensitasi atau kerusakan reseptor insulin di jaringan perifer. Penyakit DM dapat menyebabkan kematian premature, menjadi penyebab utama kebutaan, penyakit jantung dan gagal ginjal. Faktor risiko penyakit ini ada yang tidak dapat dimodifikasi/diubah seperti riwayat keluarga ataupun genetik dan faktor risiko yang dapat dimodifikasi seperti obesitas, kurangnya aktivitas fisik, merokok, hipertensi, dislipidemi dan diet tidak sehat. Diabetes melitus diklasifikasikan atas DM tipe 1, DM tipe 2, DM tipe lain dan DM pada kehamilan (Restyana Noor Fatimah, 2015).

Diabetes melitus tipe 2 (DMT2) merupakan suatu kelompok penyakit metabolik dengan karakteristik hiperglikemia, terjadi karena kelainan sekresi insulin, kerja insulin atau kedua-duanya. Sembilan puluh persen dari kasus diabetes adalah DMT2 dengan karakteristik gangguan sensitivitas insulin dan/atau gangguan sekresi insulin. DMT2 secara klinis muncul ketika tubuh tidak mampu lagi memproduksi cukup insulin unuk mengkompensasi peningkatan insulin resisten. DMT2 menjadi masalah kesehatan dunia karena prevalensi dan insiden penyakit ini terus meningkat, baik di negara industri maupun negara berkembang, termasuk juga Indonesia. DMT2 merupakan suatu epidemi yang berkembang, mengakibatkan penderitaan individu dan kerugian ekonomi yang luar biasa (Eva Decroli, 2019).

DM tipe 2 ini terjadi disebabkan oleh interaksi antara faktor genetik, lingkungan, prilaku serta gaya hidup secara bersama-sama merupakan penentu terjadinya resistensi insulin dan disfungsi sel $\beta$ pankreas. Kasus DM tipe 2 dapat dicegah dengan perubahan gaya hidup seperti menjaga berat badan, beraktivitas fisik, tidak merokok dan tidak minum minuman beralkohol. DM tipe 2 merupakan tipe yang paling banyak ditemukan di dunia, sebanyak 415 juta orang penderita pada tahun 2015 dan diperkirakan jumlahnya akan meningkat menjadi hampir 642 juta pada tahun 2040 (Dita Wahyu Hestiana, 2017).

Menanggulangi peningkatan penderita DM tipe 2 ini maka diperlukan obat yang dapat membantu penurunan kadar glukosa darah. Selain terapi farmakologi terdapat juga terapi nonfarmakologi yaitu dengan rebusan aloevera. Lidah buaya (aloe vera $L$.) merupakan tanaman yang berasal dari afrika yang sudah banyak dibudidayakan di seluruh negara di dunia. Aloe vera dapat melindungi dan mengembalikan fungsi sel $\mathrm{B}$ pankreas yang telah rusak, kandungan aloe vera juga dapat bekerja menyerupai insulin dan menurunkan kadar glukosa darah sekalipun sel B pankreas telah mengalami degenerasi karena di dalam aloevera mengandung banyak unsur mineral dan antioksidan alami misalnya vitamin $\mathrm{C}$, vitamin $\mathrm{E}$ dan mikronutrien (Kurnia \& Ratnapuri, 2019).

Salah satu mikronutrien yang efektif untuk memperbaiki kendali glukosa darah dan mencegah timbulnya komplikasi pada pasien DM adalah kromium. Kromium $(\mathrm{Cr})$ merupakan salah satu mineral trivalent essensial yang dapat menghambat Insulin Degrading Enzyme (IDE) dan Ubiquittinproteasome System (UPS) di hepar, serta menurunkan clearance dan degradasi protein yang terlibat pada jalur insulin signaling. Hal tersebut dapat meningkatkan sensitivitas insulin dan memperbaiki metabolisme 
glukosa sehingga berperan pada pengaturan kadar glukosa. Kondisi hiperglikemia mengakibatkan penurunan kadar kromium dalam tubuh dengan meningkatkan radikal bebas dan kegagalan beberapa fungsi organ sehingga berpengaruh pada kendali glukosa dan prognosis pasien DM (Satrya et al., 2019).

Sudah terdapat beberapa penelitian keefektifan lidah buaya dalam menurunkan gula darah pasien DM tipe 2 seperti penelitian yang menyebutkan bahwa lidah buaya memiliki kandungan kimia yang berkhasiat hipoglikemik diantaranya kromium, alprogen, acemannan, antraquinon, phytosterol, serta metanol sehingga aloe vera terbukti dapat menurunkan kadar glukosa darah pada pasien diabetes mellitus tipe 2 (El Qahar, 2020).

\section{METODE}

Jenis penelitian ini pre eksperimen analitik komparatif dengan rancangan penelitian Pre \& Post Test Without Control. Penelitian bertujuan untuk mengetahui pengaruh rebusan lidah buaya (aloevera) terhadap kadar gula darah pasien DM tipe 2. Populasinya adalah seluruh pasien rawat jalan yang datang ke Puskesmas Kelurahan Kebun Lada Kecamatan Binjai Utara Tahun 2020. Pengambilan sampel dengan jumlah populasi yang tidak diketahui jumlahnya maka dipakailah table cohen sebagai alat menentukan besarnya jumlah sampel. Dengan menggunakan tabel Cohen dengan power 90 , effect size 1.20 maka didapatlah sebanyak 13 orang responden. Pengambilan sampel menggunakan tehnik purposive sampling dengan kriteria inklusi penderita DM pria/wanita berusia $>50$ tahun, tidak merokok atau mengkonsumsi alkohol.

Pemberian rebusan lidah buaya dilakukan pada malam hari setelah makan malam selama 7 hari. Rebusan lidah buaya didapat dengan merebus lidah buaya dengan berat $75 \mathrm{gr}$ dengan $300 \mathrm{ml}$ air sampai mendidih. Pengukuran kadar gula darah dilakukan sebanyak 2 kali yaitu sebelum dan sesudah perlakuan, diukur pada pagi hari sebelum responden sarapan dengan menggunakan alat Autocheck Multi Monitoring System. Analisa data dilakukan secara univariat dan bivariat menggunakan uji wilcoxon.

\section{HASIL DAN PEMBAHASAN}

\subsection{Hasil}

\section{Analisis Univariat}

Hasil penelitian mendapati karakteristik responden penelitian sebagai berikut:

Tabel 1. Karakteristik Responden

\begin{tabular}{|c|c|c|}
\hline \multirow{2}{*}{\multicolumn{3}{|c|}{$\begin{array}{l}\text { No Karakteristik Responden } \\
\text { Jenis Kelamin }\end{array}$}} \\
\hline & & \\
\hline 1 Laki-Laki & 7 & 53,8 \\
\hline 2 Perempuan & 6 & 46,2 \\
\hline Total & 13 & 100 \\
\hline \multicolumn{3}{|l|}{ Umur } \\
\hline $55-60$ tahun & 7 & 53,8 \\
\hline $61-65$ tahun & 6 & 46,2 \\
\hline Total & 13 & 100 \\
\hline
\end{tabular}

Berdasarkan tabel 1 dapat dilihat bahwa kejadian penyakit diabetes melitus di Puskesmas Kelurahan Kebun Lada Kecamatan Binjai Utara terjadi pada responden berjenis kelamin laki-laki sebanyak 7 orang $(53,8 \%)$ dan perempuan sebanyak 6 orang $(46,2 \%)$ dengan kategori umur yang hampir sama jumlahnya antara usia 55 - 60 tahun sebanyak 7 orang ( 53,8\%) dengan umur 61-65 tahun sebanyak 6 orang $(46,2 \%)$.

Penelitian ini mendapati bahwa responden berjenis kelamin pria dan wanita dengan jumlah yang hampir berimbang. Hasil ini menunjukkan bahwa penyakit DM dapat dialami pria maupun/wanita. Penelitian ini sejalan dengan penelitian sebelumnya menyatakan kadar gula darah puasa tidak memiliki hubungan dengan jenis kelamin dengan $\mathrm{p}$ value sebesar 0,331 (Komariah \& Rahayu, 2020).

Usia responden dalam penelitian ini menurut Departemen Kesehatan RI (2009) dikelompokan menjadi usialansia akhir. Masa tua (lansia) merupakan masa dimana seseorang mengalami kemunduran fisik, mental dan sosial sedikit demi sedikit sehingga tidak dapat melakukan tugasnya sehari-hari lagi. Perubahan degeneratif sel-sel tubuh menyebabkan fungsi dan daya tahan tubuh menurun serta faktor resiko terhadap penyakit pun meningkat. Dengan kemampuan regeneratif yang terbatas para lansia lebih rentan terhadap berbagai sindroma dan penyakit seperti sakit jantung, osteoporosis, diabetes dan lain lain. 
Analisis Bivariat

Tabel 2. Hasil Pengukuran Kadar Gula Darah Responden Sebelum dan Sesudah Pemberian Rebusan Lidah Buaya

\begin{tabular}{cccccc}
\hline Mean & SD & Min & Max & Z & p Value \\
\hline Sebelum & $319,85 \mathrm{mg} / \mathrm{dl}$ & 96,52 & $210 \mathrm{mg} / \mathrm{dl}$ & $530 \mathrm{mg} / \mathrm{dl}$ & $-3,183$ \\
\cline { 1 - 4 } Sesudah & $299,62 \mathrm{mg} / \mathrm{dl}$ & 93,239 & $200 \mathrm{mg} / \mathrm{dL}$ & $500 \mathrm{mg} / \mathrm{dL}$ & 0,001 \\
\hline
\end{tabular}

Berdasarkan tabel 2 terlihat bahwa sebelum dilakukan pemberian rebusan lidah buaya rata-rata nilai kadar gula darah responden adalah sebesar $319.85 \mathrm{mg} / \mathrm{dl}$ dan nilai rata-rata sesudah diberikan rebusan lidah buaya adalah sebesar $299.62 \mathrm{mg} / \mathrm{dl}$. Dari hasil Uji Wilcoxon Signed Rank Test didapatkan nilai $\mathrm{Z}$ sebesar -3.183 dan nilai $\mathrm{p}$ value sebesar 0,001 lebih kecil dari tingkat alfa 5\% $(0,05)$ sehingga menolak Ho dan menerima Ha maka kesimpulannya terdapat pengaruh pemberian rebusan lidah buaya teerhadap kadar gula darah pasien diabetes mellitus tipe 2 di Puskesmas Kelurahan Kebun Lada Kecamatan Binjai Utara secara signifikan.

Hasil penelitian ini sejalan dengan penelitian sebelumnya yang melaporkan bahwa setelah diberikan olahan aloe vera yang direbus kemudian disaring dan diminum saat hangat setelah makan sebanyak 2-3 gelas perhari $(1$ gelas $=200 \mathrm{c})$ selama 5 hari berturutturut maka terjadi penurunan kadar glukosa darah pada kelompok perlakuan sebesar $62 \mathrm{mg} / \mathrm{dl}$ yaitu dari $195.40 \mathrm{mg} / \mathrm{dl}$ (pre test) menjadi $133.40 \mathrm{mg} / \mathrm{dl}$ (post test) (Kurnia \& Ratnapuri, 2019).

Sejalan juga dengan hasil penelitian yang mendapatkan rata-rata skor kadar gula darah sebelum diberikan rebusan lidah buaya sebesar 178,73mg/dl dan sesudah diberi $172,18 \mathrm{mg} / \mathrm{dl}$ dengan rata-rata penurunan 2,258. Dengan jangka pemberian intervensi selama 15 hari (Ariska, 2019).

Penurunan kadar glukosa darah pada pasien DM tipe 2 pada peneltian ini dikarenakan rebusan lidah buaya banyak mengandung senyawa seperti enzim, vitamin, mineral, asam amino dan mikronutien lain yang bermanfaat bagi kesehatan. Senyawa kimia tersebut mempengaruhi kesehatan sel pankreas penderita diabetes mellitus dengan cara memperbaiki metabolism sel yang rusak sehingga fungsi kelenjar pankreas dalam menghasilkan hormon insulin kembali normal. Berikut juga kerusakan sel reseptor insulin di membran sel pada kebanyakan terjadi pada penderita DM tipe 2 akan diperbaiki kerusakannya oleh mikronutrien dari lidah buaya sehingga penerimaan insulin kedalam sel menjadi lebih baik.

Penelitian ini sejalan dengan penelitian sebelumnya yang menyatakan bahwa salah satu mikronutrien yang efektif untuk memperbaiki kendali glukosa darah dan mencegah timbulnya komplikasi pada pasien DM adalah kromium. Kromium (Cr) merupakan salah satu mineral trivalent esensial yang dapat menghambat Insulin Degrading Enzyme (IDE) dan Ubiquittin Proteasome System (UPS) di hepar, serta menurunkan clearance dan degradasi protein yang terlibat pada jalur insulin signaling. Hal tersebut dapat meningkatkan sensitivitas insulin dan memperbaiki metabolisme glukosa sehingga berperan pada pengaturan kadar glukosa. Kondisi hiperglikemia mengakibatkan penurunan kadar kromium dalam tubuh dengan meningkatkan radikal bebas dan kegagalan beberapa fungsi organ sehingga berpengaruh pada kendali glukosa dan prognosis pasien DM (Satrya et al., 2019).

Aktiftas farmakologi Aloe vera $L$ disebutkan mengandung banyak senyawa kimia alami, seperti antrakuinon, asam amino, acemannan, aloesin, glukomanan yang bertanggungjawab memberikan efek teraupetik yang bermanfaat dalam dunia farmasi. Adapun senyawa lain sebagai penurun kadar glukosa darah yang terkandung dalam aloe vera yaitu monosakarida, polisakarida, selulosa, glukosa, mannose, aldopentosa, rhomansa yang berfungsi untuk memenuhi kebutuhan metabolisme tubuh untuk memproduksi mucopolisakarida, menekan kadar glukosa dan trigliserida post prandial dan menurunkan ratio glukosa post prandial. Lidah buaya juga memiliki berbagai aktivitas farmakologi yaitu sebagai anti inflamasi, berperan dalam penyembuhan luka, antibakteri, antifungi, antivirus, antioksidan, antikanker, antitumor, antikolesterol dan antiulcer. Penggunaan lidah buaya dalam produk farmasi juga telah mengalami perkembangan diantaranya yaitu 
sediaan nano partikel, tablet, suppositoria, gel dan krim (Kurnia \& Ratnapuri, 2019).

Tetapi hasil penelitian ini tidak sejalan dengan penelitian (Lestari, 2014) yang mendapatkan hasil tidak ada pengaruh pemberian rebusan lidah buaya (aloe vera) terhadap kadar gula darah pada penderita diabetes mellitus tipe 2 usia 40-50 tahun dimana nilai pada kelompok intervensi menunjukkan nilai $\mathrm{p}$ yaitu 0,354 , pada kelompok kontrol menunjukkan nilai p yaitu 0,381. Nilai uji Independent T-test selisih antara kelompok intervensi dan kelompok kontrol menunjukkan nilai $\mathrm{p}$ yaitu 0.473 dengan taraf signifikan 0.05 ( $>>0,05)$. Tidak adanya pengaruh pada kelompok intervensi mungkin disebabkan adanya stress yang dialami responden karena stres yang berkepanjangan akan memproduksi hormon ephineprin dan kortisol yang bekerja berlawanan dengan hormon insulin.

\section{KESIMPULAN}

Dari hasil penelitian dapat disimpulkan bahwa ada pengaruh rebusan lidah buaya terhadap penurunan kadar gula darah pada pasien DM tipe 2 di di Puskesmas Kelurahan Kebun Lada Kecamatan Binjai Utara secara signifikan dengan nilai nilai $\mathrm{Z}=-3,183$ dan $p$ value $=0.001(\mathrm{p}<0.05)$. Disarankan kepada pasien DM tipe 2 agar meneruskan mengkonsumsi rebusan lidah buaya dan rutin kontrol untuk memeriksakan kadar gula darah agar tetap stabil.

\section{REFERENCES}

Ariska. (2019). Efektifitas Pemberian Air Rebusan Lidah Buaya (Aloe Vera) Terhadap Kadar Gula Darah Pasien Diabetes Mellitus. Journal of Telenursing (JOTING), 1 .

Dita Wahyu Hestiana. (2017). Faktor-faktor Yang Berhubungan Dengan Kepatuhan
Dalam Pengelolaan Diet Pada Pasien Rawat Jalan Diabetes Mellitus Tipe 2 Di Kota Semarang. Jurnal of Health Education.

El Qahar, H. A. (2020). Pengaruh Lidah Buaya Menurunkan Kadar Glukosa Darah pada Diabetes Melitus Tipe 2. Jurnal Ilmiah Kesehatan Sandi Husada, 12 (2), 798-805. https://doi.org/10.35816/jiskh.v12i2.408

Eva Decroli. (2019). Diabetes Melitus Tipe 2 (Vol. 148).

Kementrian Kesehatan Republik Indonesia. (2020). Tetap Produktif, Cegah Dan Atasi Diabetes Mellitus. In pusat data dan informasi kementrian kesehatan RI.

Komariah, \& Rahayu, S. (2020). Oral Dengan Gula Darah Puasa Pada Pasien Diabetes Melitus Tipe 2 Di Puskesmas Baturraden. Jurnal Kesehatan Kusuma Husada, Dm, 41-50.

Kurnia, D., \& Ratnapuri, P. H. (2019). Review: Aktivitas Farmakologi Dan Perkembangan Produk Dari Lidah Buaya (Aloe vera L.). Jurnal Pharmascience, $\quad 6(1), \quad 38$. https://doi.org/10.20527/jps.v6i1.6073

Lestari, S. \& W. (2014). Pengaruh pemberian rebusan Aloe Vera Terhadap Kadar Gula Darah Pada Penderita Diabetes Mellitus Tipe 2 usia 40-50 Tahun Di Wilayah Kerja Puskesmas Wonosari I.

Restyana Noor Fatimah. (2015). DIABETES MELITUS TIPE 2. J MAJORITY, Volume 4.

Satrya, D. R., Kusumawati, S., \& Triliana, R. (2019). Pengaruh Kendali Glukosa Terhadap Kadar Kromium Pada Penderita Diabetes Melitus Tipe 2 Di Malang. 62 (341), 1-8. 